Citation: Carr, N. (2014) 'Invisible from View - Leaving and Aftercare Provision in the Republic of Ireland.' Australian Social Work, 67,1: 88-101

\title{
TITLE: INVISIBLE FROM VIEW - LEAVING AND AFTERCARE PROVISION IN THE REPUBLIC OF IRELAND
}

\section{Author: Nicola Carr}

\begin{abstract}
The adequacy of provisions for young people leaving care and in aftercare in the Republic of Ireland have been the subject of recent policy attention. A landmark report, the Ryan Report (2009), into historic abuse in state institutions recommended strengthening provisions in this area. However, the legislative basis for aftercare remains relatively weak and services for young people leaving care remain ad hoc and regionally variable. This article outlines the current context of leaving and aftercare provision in the Republic of Ireland and traces some of the recent policy debates and recommendations in this area. A genealogical analysis of leaving care and aftercare provision highlights that this issue has historically only emerged as a concern in the context in which young people leaving the care system are perceived as a 'threat' to social order. It is argued that the failure to adequately reform leaving and aftercare provision is reflective of wider social inequality and of a context in which young people in care are largely invisible from view.
\end{abstract}

\section{Introduction}

The inadequacy of provisions for young people leaving the care system in the Republic of Ireland has been raised in a number of quarters in recent years. Most prominently the Ryan Report (Government of Ireland, 2009), a landmark inquiry into historic child abuse in state institutions for children, made a recommendation that aftercare provision for young people leaving State care should be strengthened. Four years following the publication of the Ryan Report (2009), reform in this area has been minimal. Critics of the current state of affairs have argued for the need to strengthen the legislative basis for aftercare provision (Daly, 2012a, 2012b; Doyle, Mayock \& Burns, 2012), however, beyond the development of a national policy, 
which aims to standardise service provision nationally, leaving and aftercare provision in the Republic of Ireland remains discretionary, ad-hoc and inadequate.

The article begins by setting out the context of the current care system and aftercare provisions. The lack of adequate data on outcomes for young people leaving care and the limited empirical research on the care-leaving experience is highlighted. The emergence of the current system is set in the context of its historic antecedents - the Industrial and Reformatory School system. Through a genealogical analysis (Foucault, 1977), of previous inquiries into the system over the last century, the framing of calls to strengthen aftercare provisions is analysed. The question of why there has been an overall failure to reform this area is one that this article aims to critically address. This discussion is situated at the mezzo level of analysis, that is, in the wider context of the political culture and social welfare provision (Munro, Stein \& Ward, 2011; Pinkerton, 2008, 2011). It is argued that to understand the lack of visibility and the policy torpor that has characterised this area it is necessary to place the situation of care leavers in present-day Ireland in historical context by tracing the genealogy of this issue. Critically it is also argued that context of leaving care and aftercare provision cannot be understood without reference to the wider social policy and cultural frames.

\section{The Irish Care System}

The care system in Ireland is similar to many Western countries. The majority of children in care (approx. 90\%) live in foster care or kinship care. Residential care provision largely comprises of small group homes and specialist units accommodating children with more complex needs. There are also three secure residential units in the Republic of Ireland with a total capacity of 22. In 2011 there were 6,160 children in care, a rate of 5.4 per 1,000 children compared with a rate of 3.9 in 1999 (HSE, 2012a; DoHC, 2000). Data on numbers of children in care in the Republic of Ireland show that there has been a steady year by year increase in the numbers of young people in care. Between 1989 and 1999 the numbers of children in care rose by 53\% from less than 2500 to 4216 (DoHC, 2000). The current rate of children in care brings the Republic of Ireland broadly in line with neighbouring comparators (Northern 
Citation: Carr, N. (2014) 'Invisible from View - Leaving and Aftercare Provision in the Republic of Ireland.' Australian Social Work, 67,1: 88-101

Ireland, 5.8 and England, 5.9), but is significantly lower than rates for Wales (8.7) and Scotland (10.2). ${ }^{1}$

However, the current trend of increased numbers of young people in care should be placed within the wider historical context. The framework of the "modern" care system began to emerge in the 1970s alongside broader developments including the establishment of statutory social work services (Skehill, 2003; 2004) and the disestablishment of the institutional framework of the Industrial and Reformatory School system. These schools, the precursors to the current child "welfare" and "youth justice" system were established in Ireland in the mid-nineteenth century and were operated largely by Catholic religious orders such as the Christian Brothers and the Sisters of Mercy and funded by the State (Barnes, 1989; O'Sullivan, 2009). In the late nineteenth century there were 71 industrial schools in Ireland, detaining 8,000 children on any one day. By the 1950s, the system held 6,000 children per day (Raftery \& O’Sullivan, 1999).

The publication of an inquiry report (Kennedy Report) into the Reformatory and Industrial School system in 1970 is commonly cited as a key landmark in the development of a contemporary care system recommending as it did the disestablishment of institutional provision (Keenan, 1997). In truth, however, by this time the institutional system was well in decline with the numbers of schools and the population of children significantly lower than 20 years previously - by 1969 there were 2,000 children contained in thirty-one institutions (Government of Ireland, 1970). Following the publication of the Kennedy Report (1970), the government established a Task Force on Child Care Services, one of whose primary functions was to develop legislation for a contemporary care system. However, because of a range of difficulties including disagreements over departmental demarcations, new legislation governing child protection and welfare was not introduced until the early nineties.

\section{Aftercare Provision}

The Child Care Act (1991) is the main statute for child protection and welfare in Ireland. It provides the legal mechanisms for the placement of children in alternative

\footnotetext{
${ }^{1}$ Data from Department of Children and Youth Affairs, available at: http://www.dcya.gov.ie/viewdoc.asp?DocID=2585\&ad=1 Accessed on: 07.05.13
} 
care under a range of care orders. Legislative provision for aftercare is also set out in the Act. Section 45 outlines that social services may provide assistance to a young person for as long as the authorities are satisfied that a young person requires assistance up until the age of 21 . This upper age limit can be extended if the young person is in education and until such a course of education is complete. A basic outline of the form and nature of aftercare is set out in legislation - aftercare can comprise of visiting or assisting a young person, maintaining him in education, placing him in a trade and arranging hostel or other forms of accommodation (the male preposition is used throughout the legislation).

Critics of the current law have highlighted the discretionary nature of aftercare provision and have argued for the replacement of the word 'may' with 'should' in Section 45. Indeed this call was one of the central platforms of the Saving Childhood Ryan Group, a lobbying platform comprising seven organisations working with children and young people and/or adult survivors of abuse established in 2009 following the publication of the Ryan Report. Beyond calls for legislative reform the available evidence highlights that the nature and form of leaving care and aftercare arrangements in the Republic of Ireland are ad hoc and regionally variable. For example some social service areas employ specific after-care workers, but others do not, and the criteria for accessing services where they are available varies from area to area (Daly, 2012a; Doyle et al., 2012).

Overall data on the care population and those transitioning from care is also lacking. This has been most starkly highlighted recently in the context of an independent enquiry report into the deaths of children who were known to child protection services or in receipt of care and aftercare (Shannon and Gibbons, 2012), where the relevant authorities struggled to quantify the numbers of children who had died in state care over the preceding 10-year period. In response to a parliamentary question in November 2011, the Minister for Children and Youth Affairs stated that the relevant authorities did not routinely collect data on young people leaving care and those in receipt of aftercare. ${ }^{2}$ However, citing a recently commissioned consultancy report the Minister reported that in March 2011, a total of 1,051 young people were in receipt of aftercare nationally. The precise nature of this aftercare provision is unclear.

${ }^{2}$ Dáil Questions: Children in Care (03.11.11), Vol. 745, No. 3 
Citation: Carr, N. (2014) 'Invisible from View - Leaving and Aftercare Provision in the Republic of Ireland.' Australian Social Work, 67,1: 88-101

Available data from advocacy services for young people in care highlights the regional variability of service provision, and the fact that in some instances 'aftercare' comprises minimal levels of telephone contact with a worker (Daly, 2012a; Doyle et al., 2012).

The limited amount of empirical research on this area highlights similar themes (Gilligan, 2008). The small number of studies dating from the mid-1990s focussing specifically on aftercare (e.g. Kelleher \& Kelleher, 1998), or capturing data on young people who have exited the care system, such as those who have entered into homelessness (e.g. Mayock \& Carr, 2008; Mayock, O’Sullivan \& Corr, 2011), consistently pointed to a high level of unmet need. It is true that this body of research is likely to be capturing the population of young people, whom in Stein's (2006, 2012) typology would be characterised as 'strugglers', i.e. those with difficult care experiences and higher levels of need. However, a more recent empirical study on young people's experience of aftercare in one geographical area (Dublin North-East) points to inadequate preparation for young people leaving care, limited social supports and gaps in service provision. Perhaps most dispiritingly this study was conducted in an area where aftercare supports are said to be in place (Daly, 2012a).

Overall however, it is true to say that we have very limited knowledge of what happens to young people leaving care in the Republic of Ireland. Aside from the small numbers of studies cited above, there has been very little analysis of the leaving or aftercare experience, or indeed of outcomes for young people who have left the care system. It appears that this fact itself speaks to the lack of visibility of this population, who to coin Kelleher \& Kelleher's (1998) apt phrase are 'left out on their own'. The visibility of this issue, however, has been raised in recent years in the context of historic inquiries into child abuse in institutions.

\section{Ryan Report - Recommendations and Aftermath}

A Commission to Inquire into Child Abuse was established by the Irish government in 2000 to inquire into the historic abuse of children in institutions in Ireland. The decision to establish the commission followed from a number of high profile exposés of abuses perpetrated against children and young people in Industrial and Reformatory Schools over the preceding decades. The Commission's functions, set out on a statutory basis, were to inquire into the historic abuse of children in 
institutions; to provide a forum for the persons who suffered abuse to recount the abuse and make submissions: and to publish a report setting out its findings and recommendations, including the steps to be taken to deal with the continuing effects of the abuse and to protect children in similar situations in the present and in the future. In a related, but separate development, the Irish government also established a redress mechanism, the Residential Institutions Redress Board, to enable financial compensation for the victims of abuse (Brennan, 2007).

The subsequent report of the Commission, commonly referred to as the Ryan Report, was published in April 2009, 10 years after the initial decision was made to form the Inquiry. The report is voluminous comprising of five volumes and running to over 2,500 pages. The publication of the report received wide media attention, both nationally and internationally, and was viewed as a watershed moment in relation to confronting the past and setting out aspirations for the future (Flannery, 2009; Powell, Geoghegan, Scanlon \& Swirak, 2013). The recommendations made in the report (20 in total) were broadly in two categories - those relating to redress for past victims of abuse and those oriented towards preventing such abuses taking place into the future. One of the recommendations specifically related to aftercare, a recognition of the deficits in this area. Here the Commission recommended:

Children who have been in State care should have access to support services. Aftercare services should be provided to give young adults a proper support structure they can rely on. In a similar way to families, childcare services should continue contact with young people after they have left care as minors. (Government of Ireland, 2009, Vol. IV: 464)

In response to the report's publication the Irish government issued an Implementation Plan (2009) setting out how it would address each of the Commission's recommendations and here the Minister for Children, Barry Andrews, noted:

The need to support children when leaving care was highlighted by several submissions made to me and is referenced in the Commission's Report. The normal transition for young adults leaving the home is gradual and is supported. This is not the case for many children leaving care. This plan will strengthen the provision of aftercare. In addition, children on leaving care will be asked to share their ongoing experiences as they make their way through life. (OMCYA, 2009: xii) 
Citation: Carr, N. (2014) 'Invisible from View - Leaving and Aftercare Provision in the Republic of Ireland.' Australian Social Work, 67,1: 88-101

The Government's response acknowledged the fact that aftercare services "are not standardised nationally", were variable across the country and in some cases nonexistent. In response to this situation, the government committed the Health Service Executive (HSE), (the authority responsible for child protection and welfare services and care provision) to: “...ensure the provision of aftercare services for children leaving care in all instances where the professional judgment of the allocated social worker determines it is required." (OMCYA, 2009:49).

However, the recourse to individual social workers as arbiters of service provision was criticised by those campaigning for more robust reforms. The most obvious difficulty being that aftercare is not viewed as an entitlement or a right for young people leaving the care system. This discretionary element of aftercare provision is one of the reasons that various advocates have been campaigning for legislative change. Making the social worker the arbiter of service provision based on "professional judgment" may be congruent with existing legislation, but it falls short of an aspiration to address the needs of, and provide supports for, young people making the transition from care. Furthermore, the government's Implementation Plan refers to an "allocated" social worker making the necessary judgment as to whether aftercare provision is required. Another significant barrier in this process is the fact that not all children and young people in care in the Republic of Ireland have an allocated social worker, a point highlighted by recent inspectorate reports. The Health Information and Quality Authority (HIQUA) carries out inspections of health and social care services in the Republic of Ireland and routinely inspects children's residential centres, children detention schools and foster care services. A number of inspections carried out in 2013 identified that not all young people in foster care had an allocated social worker (HIQUA, 2013,a, b, c). For example, in one area (Dublin South/Dun Laoghaire), just $62 \%$ of children in foster care had an allocated social worker (HIQUA, 2013c).

A further report examining more recent practice in the child care system again brought the question of leaving care provision sharply to the fore. The Report of the Independent Child Death Review Group, an independent enquiry report examining existing information in respect of deaths of children who were known to child protection services, in care or in receipt of aftercare over a ten-year period, included 
in its recommendations a call for strengthening leaving and aftercare provision in the Republic of Ireland:

The statutory provision for aftercare should be strengthened by placing a mandatory statutory responsibility on the HSE/Child and Family Support Services Agency to ensure adequate supports are in place for vulnerable young people leaving the care system. (Shannon \& Gibbons, 2012: xvii)

However the campaign to amend legislation making leaving care provision mandatory and spearheaded by the Saving Childhood Ryan Group ultimately failed in affecting legislative change. And to date the national authority in charge of child protection and welfare services (the Health Service Executive) has developed a National Policy and Procedure Document on Leaving Care and Aftercare (2012b) but this has yet to be fully implemented. In any event the national policy reflects the legislative position. So the position of young people leaving care in the Republic of Ireland remains precarious despite the attention that this issue has garnered as described here in recent years. The question of the position and status of care leavers is not a new phenomenon however, and it is instructive to look back at how this issue has been framed over time and to explore why this policy neglect lingers.

\section{A Brief Genealogy - From Behind the Walls of the Institution}

The question of the adequacy of leaving and aftercare provision is not a new concern, and in fact the genealogy of this issue can be traced to the precursor of the current child care framework- the Industrial and Reformatory School system. The tendency of Irish society to hide 'social problems' behind institutional walls is noted in the Kennedy Report, one of the landmark inquiries into the system, in 1970:

Our whole approach to every aspect of Child Care must be based on the fact that we, the community, can no longer hide our social problems behind institutional walls we must all play our part in solving them. (Government of Ireland, 1970:59)

The question of what happened to young people when they emerged from behind the wall of the institution is the context in which the first discussions around 'aftercare' were framed. An earlier, and the first official inquiry report into the Industrial and Reformatory School System (the Cussen Report), published in 1936 explicitly considered the question of aftercare and noted the following: 
Citation: Carr, N. (2014) 'Invisible from View - Leaving and Aftercare Provision in the Republic of Ireland.' Australian Social Work, 67,1: 88-101

The early association in the public mind of the Industrial Schools with the Prison system was undoubtedly responsible for a misconception that persists even to the present day regarding these institutions and the children trained in them. The grounds, if any ever existed, for such a misconception have long since disappeared and we draw attention to this aspect of the matter, not only because the misconception is now altogether unjustifiable, but also because it affects adversely Institutions which have been remarkably successful in carrying out their self-imposed task and moreover, prejudices very seriously the prospects of the children in after-life. (Government of Ireland, 1936:10)

In what was invariably a product of its time and now reads as relatively uncritical, the report nonetheless notes the cultural stigma attached to young people who had been detained in these institutions. Echoing themes that would today be framed in the context of education and employment provision, the 1936 Report notes the inadequacy of training received by young people in institutions to prepare them for future employment. Given the specific context of 1930s Ireland with an agrarian based economy, particular reference is made to the training received in farming:

The majority of boys discharged are sent to employment in farming and allied occupations and even a large number of those trained at and discharged to trades are forced after a while to abandon such employment and to find work on farms or as general labourers...In this connection it will be noted from the reports furnished by the Technical Inspectors of the Department that the training in farming in schools is unsatisfactory, the boys apparently being regarded merely as juvenile labourers.

(Government of Ireland, 1936:30)

Identifying that the 'aftercare' of young people discharged from institutions was deficient the Commission recommended a more coordinated response, including the appointment of specific staff to carry out an aftercare role and liaise with 'charitable organisations' in the community to support young people following their discharge from the school. However, it is noteworthy that the surveillance of young people following their discharge from institutions was also fore-grounded alongside putative concerns regarding the provision of support:

The priest of the parish to which a child is sent to employment should invariably be informed of the place of residence and the name of the employer. We are aware that 
even this elementary precaution is not always taken. (Government of Ireland, 1936:34)

A subsequent interdepartmental committee established by the Minister for Justice in 1962 also explored the question of aftercare of young people discharged from Industrial and Reformatory Schools. The Report of Committee was never published, however, the Commission to Inquire into Child Abuse in the course of its public hearings heard evidence from Department of Justice officials about the impetus for looking at this area at this time:

I think the idea was that children who came out of industrial or reformatory schools that rather than just being put out on the street that there should be a support structure there... I think the Department was trying to encourage (the Department of) Education and the institutions ... [to] make arrangements for when their charges were finished in their term that there was some mechanism to get them into jobs and into a settled structured lifestyle. ${ }^{3}$

Part of the concern at the time as evidenced in questions raised in the Dáil (Irish parliament), was the destination of young people when they left state institutions. Information provided in response to a parliamentary question on the topic in 1962 outlines that the greatest proportion of young people left institutions to 'return to parents or friends' (in 1961 almost two-thirds), and that a fifth of the 947 young people discharged from institutions in 1961 were placed in some form of employment (typically menial work such as domestic labour for females or farm work for males) with another fifth entered under a 'miscellaneous category' which included emigration. (Dáil Questions: Written Answers - Industrial and Reformatory Schools, 06.12.1962, Dáil Éireann Debate Vol. 198 No. 6).

It is interesting to note that the motivation for the Department of Justice's involvement in the Industrial and Reformatory School system, or at least its discharged subjects, was a concern around future criminality, again underlining the view that young people who passed through the institutions were viewed as

\footnotetext{
${ }^{3}$ Evidence of Mr James Martin, Department of Justice before Mr Justice Seán Ryan at a public hearing of the Commission to Inquire into Child Abuse, 19.06.2006. Available at: http://www.childabusecommission.ie/about/documents/public_transcript_day227a_martin.PDF (Accessed on: 16.10.12)
} 
Citation: Carr, N. (2014) 'Invisible from View - Leaving and Aftercare Provision in the Republic of Ireland.' Australian Social Work, 67,1: 88-101

dangerous subjects. This is the rationale provided in the Department of Justice's official in evidence to the Commission to Inquire into Child Abuse in 2006:

...The Department [of Justice] obviously would be very conscious that people who aren't going [to] turn out to be structured members of a structured society they tend to end up in jail. So it has always been the view of the Department of Justice that if you are going to try to stop people from turning into criminals you want to get them at the youngest possible age, so we would have a general interest in what's happening there [referring to Industrial School]. ${ }^{4}$

However, the recommendations that the Department of Education, which had departmental responsibility for the Industrial and Reformatory Schools should develop better support structures for young people exiting institutions does not appear to have been taken any further and five years later in 1967, the government established a further Committee to Inquire into the Reformatory and Industrial School System.

The subsequent report of the Committee to Inquire into the Reformatory and Industrial School System, commonly known as the Kennedy Report (1970) recommended a preventative model of child protection and welfare which would focus on supporting families, rather than a recourse to placement in institutions. It called for the abolition of the current institutional framework, the closure of largescale institutions and a move towards a locally delivered 'group-home' model of care. Critically the report also addresses the area of 'aftercare', echoing the concerns raised in previous reports in 1936 and 1962:

We are aware that in many cases School Managers endeavour to keep in touch with children who leave their care and encourage them to return for visits or holidays. This, however, is not aftercare as it is recognised by modern thinking in child care. In practice there is no aftercare machinery and there is no specialist personnel to do this work. (Government of Ireland, 1970:56)

Here too the purpose of care and by extension the role of aftercare is the production of the "good citizen". This in fact is explicitly stated within the report as a rationale for the establishment of an "aftercare machinery":

\footnotetext{
${ }^{4}$ See previous footnote for reference.
} 
With this in mind his education should be directed towards making him a good citizen, and there should be close cooperation between those responsible for helping the child plan his education and choose a career, and those involved directly in aftercare. (Government of Ireland, 1970:56)

And the report continues:

With the closing of a number of Industrial Schools in recent times it was necessary to release numbers of children from those schools and we feel that not all the releases were purely in the best interests of the children concerned. The temptation to give precedence to the solving of an administrative difficulty over the welfare of the child must at all times be avoided. In order to avoid such dangers it is essential that every Residential Home should have an aftercare agent, who should co-ordinate the work of paving the way for a child's release into everyday life. (Government of Ireland, 1970:57)

\section{Linking the Past to the Present}

The current system of provision for child protection and welfare, including alternative care began to emerge from the 1970s onwards. This year marked the publication of the aforementioned Kennedy Report, which as outlined recommended family support as an alternative to removal of children from parental care. For children who did require a care placement the report recommended a move towards smaller groupbased homes. While the 1970s and 1980s witnessed the closure of many institutions and the establishment of what we would now recognise as the "modern" system for children in care, it took some considerable time before legislative reform was enacted in this area. It was not until the early 1990s with the introduction of the Child Care Act (1991) that the current statutory framework for child protection and welfare was established. The slow pace of reform in this area has been the subject of some critique. Gilligan (2009) for examples contrasted the range of legislation introduced to support adoption (the private sphere), with the relative neglect of what he terms the "public child", whom he defines as: "...a child whose private world has in some sense become public business, attracting attention because concern has been aroused for his or her care or safety" Gilligan (2009:265).

Another factor is relevant here, and that is the legacy of cultural stigma attached to children in care. Ferguson (2007) argues argued that part of the disavowal of 
Citation: Carr, N. (2014) 'Invisible from View - Leaving and Aftercare Provision in the Republic of Ireland.' Australian Social Work, 67,1: 88-101

responsibility for children in care by wider society is due to their construction as "other". In his historical analysis of the role of the Irish Society for the Prevention of Cruelty to Children (ISPCC), and the placement and treatment of children in institutions, he argues that these children were conceived as morally culpable and those characterisations, albeit modified in form, still persist.

So what does this mean for the current state of inaction in regard to leaving and aftercare provision? Reflecting on the wider social policy sphere various analyses of the Irish context have noted high levels of social inequality (Adshead, Kirby \& Millar, 2008). Some scholars have called for closer attention to be paid to the influence of culture on social policy (van Oorschot, 2007). Here two points are put forward. Firstly, it is important to situate aftercare provision within the wider social policy frame and secondly that social policy in this area is profoundly influenced by cultural attitudes (which are also informed by the historical context).

Up until the 1960s most social welfare-type services, as they existed (including the Industrial and Reformatory Schools) were operated, managed and delivered by the Catholic Church, with some state support in the form of capitation funding. In essence the state adopted a laissez faire approach and the Catholic Church held responsibility in this area. In the period between the 1960s and 1970s the state began to expand its role in the social sphere, evidenced by the passage of the Health Act, 1970 and the roll-out of free second level education. In the 1980s there was a retraction of social welfare services in the context of a recession. The remarkable economic growth experienced in the Republic of Ireland in the 1990s - the so called 'Celtic Tiger' led to some optimism that the spoils would be shared amongst all sections of society (Boucher and Collins, 2003).

However, as Adshead, Kirby \& Millar, (2008) noted even before the rather dramatic reversal of fortunes caused by the economic downturn the evidence of the 'glaring weaknesses' of the Irish state were evident. A report by the National Economic and Social Council (NESC) published in 2005 highlighted that the Republic of Ireland had the second highest child poverty rate in the European Union and an 18\% rate of early school leaving, and while state expenditure increased in real terms in the 1990s, it fell as a proportion of GDP. Indeed it has been frequently commented that Ireland's system of social welfare provision is more 'Boston than Berlin' - i.e. closer to the 
neo-liberal US model than European associated welfarist models (Boucher and Collins, 2003; Millar, 2008).

If, as Millar cogently argued, "the state represents the general will of Irish society towards social inclusion" (2008:102), then it can be reasonably stated that the general public doesn't will very much in this respect. The reality therefore is that changes to welfare entitlements, as a strengthening of leaving care and aftercare provision would entail, do not receive much wider cultural purchase or support. This is reflected by the fact that children and young people in this position are not viewed as a particularly powerful lobby group, and nor are their parents (Gilligan, 2009). They are paradoxically "public" yet strangely "invisible". Where events such as the Ryan Report (2009) cause attention to be focused on the care system, it is typically through the prism of the past and the situation of children in the current care system is not brought fully into view.

\section{Conclusion}

Despite a range of calls to strengthen leaving and aftercare provision in the Republic of Ireland made over recent years, the Irish government has failed to strengthen legislation in this area. Unlike its nearest UK neighbours (Northern Ireland, England and Wales), there is no separate legislation for care leavers setting out the statutory entitlements, and the existing legislation (Child Care Act, 1991) provides a weak basis for this area. In essence access to aftercare remains discretionary based on a social worker's assessment of a young person's need, which is in itself highly problematic given that recent inspection reports have highlighted the fact that not all young people in the care system have an allocated social worker (HIQUA, 2013c).

Alongside weak legislative provision there is a limited knowledge base on the actual numbers leaving care, the process of care leaving and the experience of life aftercare. It is argued that this in itself speaks to the lack of public visibility afforded young people in care and those transitioning from the system. Any analysis of the care system in Ireland has to be placed in the context of the historical patterning of widescale institutionalisation and the tendency of Irish society to hide its problems behind institutional walls. The genealogical analysis of leaving and aftercare presented in this article also supports the view that this issue has historically only emerged as concerns (in the context in which young people leaving the care system are perceived as a 
Citation: Carr, N. (2014) 'Invisible from View - Leaving and Aftercare Provision in the Republic of Ireland.' Australian Social Work, 67,1: 88-101

"threat" to social order. - i.e. in their emergence from the behind the walls of the institution and into the public view.

Arguments that the provision of adequate leaving and aftercare services is a "good" in and of themselves have been made more latterly, but the reality is that there has been little material effect. Here the wider social policy context is also important, and in a country with high levels of social inequality the needs of young people exiting care are low down the policy agenda. The emergence of a rights-based discourse towards child protection and welfare - evidenced by the fact that the Republic of Ireland ratified the United Conventions on the Rights of the Child (UNCRC) in 1992 - and the articulation of rights based language in the Child Care Act, 1991, could give some reason for optimism (Munro, Pinkerton, Mendes, Hyde-Dryden, Herczog \& Benbenishty, 2011). However, the translation of rights beyond the text and into practice remains a perennial struggle. In November 2012, a historic referendum was held to insert a clause into the Irish Constitution specifically recognising children's rights. The need for a constitutional amendment had been the subject of debate from the early 1990s, as children were not recognised as independent rights-bearers in the Constitution. However, only a third of the electorate turned out to vote through this historic amendment. ${ }^{5}$

The argument put forward in this article is that cultural attitudes towards children and young people and specifically towards young people in the care system have played a role in the policy stasis in this area. A real strengthening of the area of leaving and aftercare provision in the Republic of Ireland will require reference to wider social inequalities and a focus on bringing the experiences, needs and aspirations of young people in care and those leaving care more into the public view.

5 Irish Times, 11.11.12 - 'Children's referendum passed amid low turnout.' Available at: http://www.irishtimes.com/newspaper/breaking/2012/1111/breaking1.html 


\section{References}

Adshead, M., Kirby, P. \& Millar, M. (2008). Contesting the State. Lessons from the Irish case. Manchester: Manchester University Press

Barnes, J. (1989). Irish Industrial schools 1868-1908. Origins and development. Dublin: Irish Academic Press

Boucher, G. and Collins, G. (2003). Having one's cake and being eaten too: Irish neoliberal corporatism, Review of Social Economy, 61, 3: 295-316

Brennan, C. (2007). Facing what cannot be changed: The Irish experience of confronting institutional child abuse. Journal of Social Welfare and Family Law, 29, 3-4: $245-263$

Daly, F. (2012a). My voice has to be heard. Research on outcomes for young people leaving care in North Dublin. Dublin: EPIC

Daly, F. (2012b). What do young people need when they leave care? Views of careleavers and aftercare workers in North Dublin. Child Care in Practice, 18,4: 309-324

Department of Health and Children (2000). Preliminary analysis of childcare interim dataset. Dublin: DoHC

Doyle, A., Mayock, P. \& Burns, K. (2012). Aftercare not afterthought: Supporting children in care's transition to adulthood. In: K. Burns \& D. Lynch (Eds.) Children's rights and child protection: Critical times, critical issues in Ireland. Manchester: Manchester University Press (p.202-222)

Ferguson, H. (2007). Abused and looked after children as "moral dirt": Child abuse and institutional care in historical perspective. 'Journal of Social Policy, 36,1: 123139

Flannery, T. (Ed.) (2009). Responding to the Ryan Report. Dublin: The Columba Press

Foucault, M. (1977) (1991). Discipline and punish. The birth of the prison. London: Penguin

Gilligan, R. (2008). “Ireland”. In: M. Stein \& E.R. Munro (Eds.) Young people's transitions from care to adulthood. London: Jessica Kingsley (p.90-102)

Gilligan, R. (2009). The "public child" and the reluctant state?' Éire-Ireland, 44, 1\&2: $265-290$

Government of Ireland (1936). Commission of inquiry into the Reformatory and Industrial school system 1934-1936. (Cussen Report). Dublin: The Stationery Office

Government of Ireland (1970). Report of the committee of inquiry into Reformatory and Industrial school systems. (Kennedy Report) Dublin: Stationery Office

Government of Ireland (2009). Commission to inquire into child abuse (CICA) (Vols I-V) (Ryan Report) Dublin: Stationary Office 
Citation: Carr, N. (2014) 'Invisible from View - Leaving and Aftercare Provision in the Republic of Ireland.' Australian Social Work, 67,1: 88-101

Health Service Executive (HSE) (2012a). Review of adequacy for HSE children and family services. Dublin: HSE

Health Service Executive (HSE) (2012b). Leaving and aftercare services, national policy and procedures Document. Dublin: HSE

HIQUA (Health Information and Quality Authority) (2011). Report on a follow-up inspection of the Health Service Executive fostering service in HSE Dublin North central area. Dublin: HIQUA

HIQUA (Health Information and Quality Authority) (2013a) Inspection of the HSE Laois Offaly Local Health Area fostering service in the Dublin mid-Leinster integrated service area. Dublin: HIQUA

HIQUA (Health Information and Quality Authority) (2013b) Inspection of the HSE Wexford Local Health Area fostering service in the Waterford/Wexfprd integrated service area. Dublin: HIQUA

HIQUA (Health Information and Quality Authority) (2013c) Inspection of the HSE Dublin South/Dun Laoighre Local Health Area fostering service in the Dublin South/East Wicklow integrated service area. Dublin: HIQUA

Keenan, O. (1997). Child welfare. In Robins, J. (Ed) Reflections on health: Commemorating fifty years of the Department of Health, 1947-1997. Dublin: Institute of Public Administration. pp.65-66

Kelleher, P. \& Kelleher, C. (1998). Out on their own-young people leaving care in Ireland. Dublin: Focus Point

Mayock, P. \& Carr, N. (2008). Not just homelessness... a study of "out of home" young people in Cork city. Cork: Health Service Executive

Mayock, P., O’Sullivan, E. \& Corr, M.L. (2011). Young people exiting homelessness: an exploration of process, meaning and definition. Housing Studies, 26, 6, 803-826

Millar, M. (2008). Social inclusion and the welfare state: who cares? In: M. Adshead, P. Kirby \& M. Millar (Eds.) Contesting the State. Lessons from the Irish case. Manchester: Manchester University Press (p. 50-73)

Munro, E.R., Stein, M. \& Ward, H. (2005). Comparing how different social, political and legal frameworks support or inhibit transitions from public care to independence in Europe, Israel, Canada and the United States. International Journal of Child and Family Welfare, 8,4: 191-202

Munro, E.R., Pinkerton, J., Mendes, P., Hyde-Dryden, G., Herczog, M and Benbenishty, R. (2011). The contribution of the United Nations Convention on the Rights of the Child to understanding and promoting the interests of young people making the transition from care to adulthood. Children and Youth Services Review, 33,12: $2417-2423$

National Economic Social Council (NESC (2005)). The developmental welfare State. 
Dublin: National Economic and Social Council

Office of the Minister for Children and Youth Affairs (2009). Report of the Commission to Inquire into Child Abuse implementation plan. Dublin: OMCYA

O'Sullivan, E. (2009). Residential child welfare in Ireland, 1965-2008. Commission to Inquire into Child Abuse, Vol. (IV). Dublin: Stationary Office

Pinkerton, J. (2008). States of care leaving: towards international exchange as a global resource. In: M. Stein \& E.R. Munro (Eds.) Young people's transitions from care to adulthood. London: Jessica Kingsley (p.241-258)

Pinkerton, J. (2011). Constructing a global understanding of the social ecology of leaving out of home care, Children and Youth Services Review, 33, 12: 2412-2416

Powell, F., Geoghegan, M., Scanlon, M. \& Swirak, K. (2013). 'The Irish charity myth, child abuse and human rights: contextualising the Ryan Report into care institutions.' British Journal of Social Work, 43,1: 7-23

Raftery, M. and O'Sullivan, E. (1999). Suffer the little children: the inside story of Ireland's Industrial Schools. Dublin: New Island Books

Shannon, G. \& Gibbons, N. (2012). Report of the independent child death review group. Dublin: Government Publications

Skehill, C. (2003). 'Social work in the Republic of Ireland. A history of the present.' Journal of Social Work, 3,2: 141-151

Skehill, C. (2004). History of the present of child protection and welfare social work in Ireland. Lampeter: Edwin Mellen

Stein, M. (2006). 'Research review: young people leaving care.' Child and Family Social Work, 11,3: 422-435

Stein, M. (2012). Young people leaving care. Supporting pathways to adulthood. London: Jessica Kingsley Publishers

Stein, M. \& Munro, E.R. (Eds.) (2008). Young people's transitions from care to adulthood. London: Jessica Kingsley Publishers

van Oorschot, W. (2007). 'Culture and social policy: a developing field of study.' International Journal of Social Welfare, 16, 2: 129-139 